Int. J. Electrochem. Sci., 14 (2019) 2187 - 2207

\title{
Corrosion Protection of Stainless Steel 201 in Acidic Media using Novel Hydrazine Derivatives as Corrosion Inhibitors
}

\author{
A. S. Fouda ${ }^{1, *}$, S. A. Abd El-Maksoud ${ }^{2}$, A. El-Hossiany³, A. Ibrahim ${ }^{1}$ \\ ${ }^{1}$ Department of Chemistry, Faculty of Science, El-Mansoura University, El-Mansoura-35516, Egypt, \\ ${ }^{2}$ Department of Chemistry, Faculty of Science, Port Said University, Egypt \\ ${ }^{3}$ Chemist, Delta Fertilizers Company in Talkha, Egypt \\ *E-mail: asfouda@hotmail.com, asfouda@mans.edu.eg
}

doi: $10.20964 / 2019.03 .15$

Received: 3 November 2018 / Accepted: 25 December 2018 / Published: 7 February 2019

This study aimed at the application of hydrazine derivatives (HZD) in acid media as corrosion inhibitors of stainless steel 201 (SS201). In the chemical and electrochemical technique, SS201 is the constructional material widely used. The various factors, which influence the corrosion inhibition efficiency of different HZD have been discussed. Different techniques were used to evaluate the corrosion inhibition. Atomic force microscopy (AFM) and FTIR were utilized to study the surface morphology of SS201which revealed that the inhibitors produce a thin film adsorbed on the surface of SS201.

Keywords: SS201, Hydrazine derivatives, $\mathrm{HCl}$, Corrosion inhibition, AFM, FTIR

\section{$\underline{\text { FULL TEXT }}$}

(C) 2019 The Authors. Published by ESG (www.electrochemsci.org). This article is an open access article distributed under the terms and conditions of the Creative Commons Attribution license (http://creativecommons.org/licenses/by/4.0/). 